Eur. J. Clin. Chem. Clin. Biochem.

Vol. 32, 1994, pp. 745-747

(c) 1994 Walter de Gruyter \& Co.

Berlin · New York

\title{
Serum Total Sialic Acid and Acute Phase Proteins in Elderly Subjects
}

\author{
By M. A. Crook ${ }^{1}, A$. Treloar ${ }^{2}, M . H^{2} q^{1}$ and P. Tutt ${ }^{1}$ \\ 1 Department of Clinical Chemistry, Guy's Hospital, London, England, U. K. \\ 2 Section of Psychogeriatrics, Division of Psychiatry, United Medical and Dental Schools, Guy's Hospital, London, \\ England, U.K.
}

(Received June 29/July 26, 1994)

Summary: Serum total sialic acid has gained recent interest as a cardiovascular risk factor. We measured serum total sialic acid and three acute phase proteins; $C$-reactive protein, $\alpha_{1}$-antichymotrypsin and $\alpha_{1}$-acid glycoprotein in 37 geriatric patients (age 80.1 \pm 7.0 years) and 50 younger subjects (age $40.3 \pm 11.4$ years). Serum total sialic acid was higher in the geriatric subjects $2.41 \pm 0.39 \mathrm{mmol} / \mathrm{l}$ versus $2.04 \pm 0.35 \mathrm{mmol} / 1, \mathrm{P}<0.04$. Serum $\alpha_{1}$-acid glycoprotein, $\alpha_{1}$-antichymotrypsin and C-reactive protein were also elevated in the geriatric patients; serum $\alpha_{1}$-acid glycoprotein being $1.16 \pm 0.32 \mathrm{~g} / \mathrm{l}$ versus $0.41 \pm 0.28 \mathrm{~g} / \mathrm{l}, \mathrm{P}<0.0001$, serum $\alpha_{1}$-antichymotrypsin being 0.80 $\pm 0.20 \mathrm{~g} / \mathrm{l}$ versus $0.52 \pm 0.10 \mathrm{~g} / \mathrm{l}, \mathrm{P}<0.0001$ and serum $C$-reactive protein being $9.71 \pm 21.0 \mathrm{mg} / \mathrm{l}$ versus 4.73 $\pm 1.30 \mathrm{mg} / \mathrm{l}, \mathrm{P}<0.04$. There was a correlation with serum total sialic acid and serum $\alpha_{1}$-acid glycoprotein and $\alpha_{1}$ antichymotrypsin in the geriatric subjects and with $\alpha_{1}$-acid glycoprotein, $\alpha_{1}$-antichymotrypsin and $C$-reactive protein in the younger group.

\section{Introduction}

Increased serum total sialic acid has been shown to be a cardiovascular risk factor $(1,2)$ and also a cerebrovascular risk factor (3). Serum total sialic acid is elevated in diabetes mellitus (4-6), after myocardial infarction $(7,8)$ in patients with chronic glomerulonephritis $(9)$ and inflammatory bowel disease (10). Serum total sialic acid has also been used as a tumour marker for a number of different cancers, including malignant melanoma, breast and colon carcinoma $(11-14)$. It has been suggested that elevated serum total sialic acid may reflect an acute phase response (15). Many of the serum acute phase proteins are glycoproteins and some have sialic acid residues located within their carbohydrate sidechains. Although there have been several studies of serum total sialic acid in young and middle aged human populations $(16-17)$ there have been few studies that have evaluated serum total sialic acid concentrations in the elderly.

\section{Methods \\ Subjects}

Thirty-seven patients from a psychogeriatric hospital (age 80.1 \pm 7.0 years) were studied and also fifty younger aged subjects
(40.3 \pm 11.4 years). Geriatric patients with diabetes mellitus (as judged by random blood glucose concentration of more than 11.1 $\mathrm{mmol} / \mathrm{l}$ ), known infection or tumour, cardiovascular disease, recent operations or any other known causes of an acute phase response were excluded by relevant clinical history and physical examination. In the geriatric group there were 18 females and 19 males, whereas in the younger aged group there were 27 females and 23 males. There was no difference in the proportion of the sexes between the two groups. The younger subjects were either healthy blood donors or normal individuals who were part of a health screening program. None of the subjects had diabetes mellitus (random blood glucose of less than $11.1 \mathrm{mmol} / \mathrm{l}$ ) and they also had no recent infections, myocardial infarctions, operations or known malignant disease.

Serum total sialic acid, albumin and total protein along with the acute phase proteins: $C$-reactive protein, $\alpha_{1}$-acid glycoprotein and $\alpha_{1}$-antichymotrypsin were assayed upon the same blood sample. Serum globulin concentration was calculated as the difference between serum total protein and serum albumin concentrations.

Assays

Serum total sialic acid was assayed using an enzymatic method purchased from Boehringer Mannheim, (Lewes, Sussex, England) on a Roche Cobas Bio analyser. This method uses a coupled enzyme assay reaction, incorporating neuraminidase, $\mathrm{N}$-acetylneuraminic acid aldolase and pyruvate oxidase linked to a peroxidase dye system. The intra-batch coefficient of variation was $3.8 \%$. The serum acute phase proteins were assayed immunoturbidimetrically, using commercial kits from Binding Site (Binding Site Ltd. Birmingham, UK) on a Cobas Mira analyser. Scrum albumin and total 
protein were assayed using a Kodak Ektachem analyser (Kodak Ltd, USA).

\section{Statistics}

Results are shown as mean \pm standard deviation. Differences between groups were compared using the Mann-Whitney test and the degree of correlation by using the Spearman correlation coefficient (rho). Significance was taken as $\mathrm{P}$ being less than 0.05 .

\section{Results}

Subject age, sex distribution and serum total sialic acid and acute phase proteins are depicted in table 1 . There was a significant difference in serum total sialic acid between the two groups being higher in the geriatric subjects. Serum $\alpha_{1}$-acid glycoprotein, $\alpha_{1}$-antichymotrypsin and C-reactive protein were significantly elevated in the geriatric patients as compared to the younger aged group. Serum albumin was significantly lower in the geriatric subjects, whereas, the serum globulin concentration was elevated in the geriatric subjects.

Serum total sialic acid correlated significantly with serum C-reactive protein, $\alpha_{1}$-antichymotrypsin and $\alpha_{1}$-acid glycoprotein in the younger aged subjects but only with serum $\alpha_{1}$-antichymotrypsin and weakly with $\alpha_{1}$-acid glycoprotein in the geriatric group. Spearman correlation coefficients and statistical significance for the geriatric and younger aged subjects are depicted in table 2 .

Tab. 1 Age, serum sialic acid and acute phase proteins for the geriatric and younger subjects. $+P<0.04, * P<0.0001$. The ranges for the data are shown in parentheses.

\begin{tabular}{lcc}
\hline & Geriatric subjects & Younger subjects \\
\hline Age (years) & $80.1 \pm 7.0$ & $40.3 \pm 11.4$ \\
Sex $\left(\mathrm{g} / \delta^{\prime}\right)$ & $189 / 19 \delta^{*}$ & $279 / 23 \delta^{*}$ \\
Serum total sialic acid & $2.41 \pm 0.39$ & $2.04 \pm 0.35+$ \\
$\quad(\mathrm{mmol} / \mathrm{l})$ & $(1.6-3.7)$ & $(1.2-2.7)$ \\
C-reactive protein & $9.71 \pm 21.0$ & $4.73 \pm 1.30+$ \\
$\quad(\mathrm{mg} / \mathrm{l})$ & $(1-123.5)$ & $(3.5-12.1)$ \\
$a_{1}$-Acid glycoprotein & $1.16 \pm 0.32$ & $0.41 \pm 0.28^{*}$ \\
$\quad(\mathrm{~g} / \mathrm{l})$ & $(0.73-2.03)$ & $(0.17-0.95)$ \\
$\alpha_{1}$-Antichymotrypsin & $0.80 \pm 0.20$ & $0.52 \pm 0.10^{*}$ \\
$\quad(\mathrm{~g} / \mathrm{l})$ & $(0.40-1.45)$ & $(0.29-0.74)$ \\
Albumin $(\mathrm{g} / \mathrm{l})$ & $36.9 \pm 3.1$ & $43.8 \pm 3.7^{*}$ \\
& $(31.0-43.0)$ & $(34.0-52.0)$ \\
Protein $(\mathrm{g} / \mathrm{l})$ & $70.3 \pm 7.0$ & $71.3 \pm 5.3$ \\
& $(58.0-86.0)$ & $(59.0-80.0)$ \\
Globulin $(\mathrm{g} / \mathrm{l})$ & $33.5 \pm 5.2$ & $28.0 \pm 3.7^{*}$ \\
& $(24.0-43.0)$ & $(17.0-35.0)$ \\
\hline
\end{tabular}

Tab. 2 Spearman correlation coefficients ( $r$ ) and statistical significance $(p)$ for serum total sialic acid against serum acute phase proteins for the geriatric and younger subjects.

\begin{tabular}{|c|c|c|c|c|c|c|}
\hline \multirow[b]{2}{*}{$\begin{array}{c}\text { C-reactive } \\
\text { protein }\end{array}$} & \multicolumn{3}{|c|}{ Geriatric subjects } & \multicolumn{3}{|c|}{ Younger subjects } \\
\hline & $r=$ & 0.10 & $\dot{p}=0.28$ & $r=$ & 0.61 & $p<0.0001$ \\
\hline $\begin{array}{l}\alpha_{1} \text {-Acid } \\
\text { glyco- } \\
\text { protein }\end{array}$ & $r=$ & 0.32 & $p=0.03$ & $\mathrm{r}=$ & 0.29 & $p=0.03$ \\
\hline $\begin{array}{l}\alpha_{1} \text {-Anti- } \\
\text { chymo- } \\
\text { trypsin }\end{array}$ & $r=$ & 0.48 & $\mathrm{p}=0.001$ & $r=$ & 0.79 & $\mathrm{p}<0.0001$ \\
\hline Albumin & $\mathrm{r}=$ & -0.01 & $p=0.49$ & $r=$ & -0.05 & $p=0.38$ \\
\hline Protein & $r=$ & 0.06 & $p=0.36$ & $r=$ & 0.11 & $p=0.24$ \\
\hline Globulin & $r=$ & 0.09 & $p=0.29$ & $r=$ & 0.18 & $p=0.12$ \\
\hline
\end{tabular}

\section{Discussion}

Although we accept that it is very difficult to exclude underlying organic pathology in psychogeriatric patients we were careful to eliminate individuals with conditions known to elicit an acute phase protein response. In any case it would be equally difficult to exclude conditions causing an acute phase response in any group of geriatric subjects. The underlying mechanism for the elevation of serum total sialic acid in elderly subjects may be due to a concomitant elevation of serum acute phase proteins many of which are known to be sialylated. Further support of this hypothesis comes from the significant correlation between serum total sialic acid and some of the acute phase proteins, namely serum $\alpha_{1}$-antichymotrypsin and $\alpha_{1}$-acid glycoprotein in the geriatric subjects and serum C-reactive protein, $\alpha_{1}$-antichymotrypsin and $\alpha_{1}$ acid glycoprotein in the younger subject group. We except, however, that these correlations are weak particularly in the geriatric subjects.

The three positive acute phase proteins measured in our study were chosen for the following reasons; $\alpha_{1}$-acid glycoprotein is a richly sialylated glycoprotein, serum C-reactive protein is elevated for a short time as a result of an acute phase protein response, whereas the serum $\alpha_{1}$-antichymotrypsin response tends to be prolonged. We should state, however, that C-reactive protein is not thought to be sialylated (18). Our findings also support those of Taniuchi et al. (15) who found that serum total sialic acid was related to some of the acute phase proteins in subjects after a myocardial infarction. Furthermore, our observations expand upon those of Milman and co-workers who earlier reported that erythrocyte sedimentation rate, fibrinogen, haptoglobin and $\alpha_{1}$-antitrypsin were also elevated in the elderly (19). However, these workers did not measure serum sialic acid in their study. We should state, however, that serum total sialic 
acid was only moderately elevated in the elderly subjects and there was some overlap in the serum total sialic acid ranges between the two groups. The explanation is unclear but may reflect heterogeneity of levels of acute phase proteins or differing degrees of glycoprotein sialylation in these individuals.

Serum total sialic acid is likely to be measured more frequently in hospital practice. The novel findings presented in this paper suggest that age considerations should be made when attempting to interpret serum total sialic acid levels. We can only speculate as to why the

\section{References}

1. Lindberg, G., Eklund, G., Gullberg, B. \& Rastam, L. (1991) Serum sialic acid concentration and cardiovascular mortality. Brit. Med. J. 302, 143-146.

2. Lindberg, G., Eklund, G. A. \& Rastam, L. (1991) Serum sialic acid concentration and smoking: A population based study. Brit. Med. J. 303, 1306-1307.

3. Lindberg, G., Rastam, L., Gullberg, B. \& Eklund, G. A. (1992) Serum sialic acid concentration predicts both coronary heart disease and stroke mortality: Multivariate analysis including 54385 men and women during 20.5 years follow up. Int. J. Epidemiol. 21, 253-257.

4. Radhakrishnamurthy, B., Berenson, G. S. \& Pargaonar, P. S. (1976) Serum free and protein bound sugars and cardiovascular complications in diabetes mellitus. Lab. Invest. 34, 159165.

5. Schvartz, L. S. \& Paukman, L. I. (1971) Diabetic angiopathies and mucopolysaccharide metabolism. Probl. Endokrinol. (Mosk) 17, 37-41.

6. Crook, M., Tutt, P. \& Pickup, J. C. (1993) Serum sialic acid in non-insulin dependent diabetes mellitus. Diabetes Care 16, $57-60$.

7. Hrncir, Z., Pidrman, V., Tichy, M. \& Hamet, A. (1975) Serum sialic acid in acute myocardial infarction in a dynamic follow up. Vnitr Lek. 21, 436-439. English Abstract.

8. Succari, M., Foglietti, M. J. \& Percheron, F. (1982) Perchlorosoluble glycoproteins and myocardial infarct: Modifications of the carbohydrate moiety. Pathol. Biol. (Paris) 30, 151-154. English Abstract.

9. Ozben, T. (1991) Elevated serum and urine sialic acid in renal diseases. Ann. Clin. Biochem. 28, 44-48.

10. Baba, R., Yashiro, K., Nagasako, K. \& Obata, H. (1992) Significance of serum sialic acid in patients with Crohn's disease. Gastroenterologia Japonica 27, 604-610. serum acute phase proteins are elevated in the elderly, but presumably they are more likely to have atherosclerosis than a younger population and Stuart and coworkers have shown that this can result in an elevation of serum acute phase proteins (20).

\section{Acknowledgements}

We are grateful to the Guy's Trustees and the Wellcome Foundation for support during this project. Napp laboratories also kindly provided funding. We are also indebted to Dr. M. Philpot and to the patients and staff of Bexley Hospital.
11. Hogan-Ryan, A., Fennelly, J. J., Jones, M., Cantwell, B. \& Buffy, M. J. (1980) Serum sialic acid and CEA concentrations in human breast cancer. Br. J. Cancer 41, 587-592.

12. Horgan, I. E. (1982) Total and lipid-bound sialic acid levels in sera from patients with cancer. Clin. Chim. Acta 118, 327331.

13. Mabry, E. W. \& Carubelli, R. (1972) Sialic acid in human cancer. Experientia 28, 182-183.

14. Stefenelli, N., Klotz, H., Engel, A. \& Bauer, P. (1985) Serum sialic acid in malignant tumours, bacterial infections and chronic liver diseases. J. Cancer Res. Clin. Oncol. 109, 55-59.

15. Taniuchi, K., Chifu, K. \& Hayashi, N. (1981) A new enzymatic method for the determination of sialic acid in serum and its application for a marker of acute phase reactants. Kobe J. Med. Sci. 27, 91-102.

16. Hangloo, V. K., Kaul, I. \& Zargar, H. U. (1990) Serum sialic acid levels in healthy individuals. J. Postgrad. Med. 36, 140-142.

17. Lorentz, K., Weiss, T. \& Kraas, E. (1986) Sialic acid in human serum and cerebrospinal fluid. Comparison of methods and reference values. J. Clin. Chem. Clin. Biochem. 24, 189-198.

18. Thompson, D., Milford-Ward, A. \& Whicher, J. T. (1992) The value of acute phase protein measurements in clinical practice. Ann. Clin. Biochem. 29, 123-131.

19. Milman, N., Graudal, N. \& Andersen, H. (1988) Acute phase reactants in the elderly. Clin. Chim. Acta 176, 59-62.

20. Stuart, J., George, A. J., Davies, A. J., Aukland, A. \& Hurlow, R. A. (1981) Haematological stress syndrome in atherosclerosis. J. Clin. Pathol. 34, 464-467.
Dr. M. A. Crook
Clinical Chemistry
$5^{\text {th }}$ Floor Tower
Guy's Hospital
London SE1 9RT
England, U.K. 


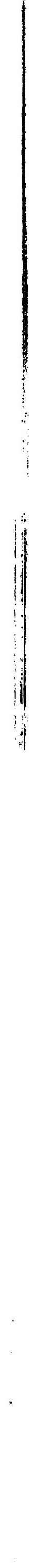

